\title{
Conflict in Cross Border Higher Education: Franchised Cross Border Ethiopian Universities in Somaliland Higher Education
}

\author{
Rawling Wondemneh, \\ $\mathrm{Ph} . D$. student, School of Education, Huazhong University of Science and \\ Technology, Wuhan, P.R. China \\ Hong Shen, \\ Professor, Director of the Center for Higher Education Research, Southern \\ University of Science and Technology, Shenzen P.R. China
}

Doi:10.19044/esj.2020.v16n19p143 URL:http://dx.doi.org/10.19044/esj.2020.v16n19p143

\begin{abstract}
This study deals with the conflict of franchised cross-border higher education. The constitution of Somaliland on article 15 No.4 loosen the gate of education for foreign institutions, but bilateral relation between Ethiopian universities and Somaliland higher education is experiencing conflicts. The conflicts are between franchisor and franchisee and among franchisee shareholders. The reasons for the problem are unknown since the existence of cross-border foreign universities in Somaliland. Therefore, the aim of this study was to assess the reasons behind the conflicts and the effect of the conflicts on the learning-teaching. Case study design was applied. The research approach was qualitative, and both primary and secondary sources of data were employed. Interview, document analysis, focus group discussion (FGD), and observation were drawn for data instruments. The results show that the franchising mode of contract/agreement is not respected by the shareholders, absence of trust is existed in franchised relationship, the involvement of the Somaliland National Commission for Higher Education (SNCHE) is late on the contract and conflicts, the higher education is running without higher education policy, interruption of the learning-teaching, student transfer, and stakeholders suspicion towards cross border universities. The country has joined the world map after Somalia's destructive civil war and focused on development in many aspects. Likewise, the researcher planned to contribute tangible asset for the recently emerged Somaliland National Commission for Higher Education. So that it initiates local or international researchers in this area for further researches.
\end{abstract}


Keywords: Cross-border higher education, conflict, franchising mode, Somaliland higher education

\section{Introduction}

Cross-border education refers to the movement of programs, people, professors, providers, knowledge, ideas, projects, learning material, curricula, researchers and services across boundaries (Knight, 2010). Borderless, transnational, border crossing, offshore, distance, overseas and other similar terminologies are used alternatively for Cross-border education.

In sub-Saharan African Countries, universities and colleges do not have long experience of one another cross-border higher education. However, this area's too many students have crossed the border for higher education via their country government sponsor, other partner countries sponsor, or selfsponsor. Part of east Africa, where Somaliland and Ethiopia found, has been practicing cross-border education since the beginning of the 1960s to the ending of the 1970s. The University of East Africa's cross-border education experience at three different universities in Uganda, Kenya and Tanzania was known. (Lane \& Kinser, 2013)

In Somaliland, the country's constitution provoked both foreigners and local people to encompass in the education sector of any levels based on educational rules and regulations. The English version of the country's constitution under the article title: Education, Youth and Sports, mentioned that citizens and resident foreigners might open schools and educational or training projects of all levels in accordance with the Education Law (Government, 2000). This shows how the country opened its gate to education for both foreign and local citizens and how it gave immense courtesy to the development of education.

In Ethiopia, higher education expansion and reform programmes of impressive dimensions are embarked (Saint, 2004). To this end, Ethiopian universities committed not only inside the country but also crossing the border and realize higher education expansion and try to ensure quality learning teaching and producing professionals. Ethiopian institutions crossing the border and emerged to Somaliland higher education is more desirable.

Admas University (at the time, it was a university college) lit the light of cross border private higher education in the country's capital Hargeisa. Somaliland's first-ever university Amoud was functional (Ali, 2014). The public and local private universities Hargeisa and Gollise respectively were also functional, but the rest were not. Admas was franchised and started four fields of study. From Admas's arrival on, students who have successfully finished their primary and secondary education have started registration in the university as an undergraduate student. As (Bekalo, Brophy, \& Welford, 2003) 
has mentioned that the basic '4-4-4-4' structure (4 years lower primary, 4 years upper primary, 4 years secondary and 4 years of tertiary education) is the underlying basic framework of formal education of Somaliland.

The opening of Admas University College in 2006 forced both Amoud and Hargeisa University, which had few departments, to arrange an extra workforce and to commence other more departments. To that end, both public and private institutions of higher education, bourgeoning many departments today, play an irreplaceable role. Two years later, Addis Ababa Medical University college (at the time, it was a college) joined Somaliland higher education, with few students in two departments (Clinical Nursing and Public Health). Then after, other eight universities: Lucy, New generation, Addis, Horn, Kia-Med, Riftvally, Unity, Jimma join to Somaliland higher education and become a total of ten, within thirteen years since 2006 to 2019. Besides, extra campuses have opened in Borema, Berbera, and Buro cities.

The government universities in the present day are attracted to be part of Somaliland higher education. Currently, even one of the popular government universities in Ethiopia, Jimma has crossed the border and signed a partnership agreement with United Enterprise and started a research-based Masters program in Nutrition, Project Management, and Reproductive Health.

Previous researches on cross border education focused on developed countries' border crossing universities. Indeed, in developing countries, researches were conducted on cross border education as well, but they did not focus on reason and the wide effect of conflict on education. The effects of conflict on education are now large and varied (Bertoni, Di Maio, Molini, \& Nisticò, 2018), and conflict has been hosted in many academic disciplines (Massey \& Miller, 2018).

In Somaliland, franchisor \& franchisee conflict and conflict among shareholders of franchisee arise in different universities over and over again. This conflict is most of the time happened among franchisee of the receiver country B. In some other cases; the conflict occurred between franchiser of provider country A and franchisee of receiver country B. The conflict had not been taken as serious issues at first. Later, it became visible in every academic year and became familiar in higher education institutions and known by stakeholders, especially by the students. To see a simple example of the conflict, Lucy University has been totally stopped the learning-teaching process and replaced it by another university called Alpha. Here degree level programs in the university, which was on progress, discontinued for a franchisor $\&$ franchisee conflict, and almost all students left and join to another university. The remaining few students of Lucy University continue their programs with newly replacing Alpha university.

In another instance, Addis Ababa Medical University College (AAMUC) has interrupted \& started again the learning-teaching process for 
four academic years, and still, the court issue between the plaintiff and defendant is on progress and keeps on alarming for the interruption of the flow of learning-teaching. Even Admas, a university having too many students among all Ethiopian universities in Somaliland, had faced a similar problem. The same was true in both New Generation and Horn Universities. Recently in 2017, the same problem has happened in Addis College. Such kinds of conflicts raise big questions like universities' learning-teaching quality, access, governance, and higher education policy.

The conflict over the franchising mode agreement was only announced via mass media as news. More than that, the cause of the conflict and its effect is neither clear nor followed by research attention. Shareholders give more focus on the court's progress of the conflict to search the system on how they survive for extra academic years instead of assuring and maintaining their quality education. A study has mentioned Japanese quality control guru, William Edwards Deming lecture saying: Quality is not something you install like a new carpet or set of bookshelves...You implant it. Quality is something you work at. It is, thus, a learning process (Aga, 2006). But the campuses' attention is less towards maintaining quality. The conflict dragged to another way, which deteriorates the learning-teaching process.

Besides, as a country, Somaliland's higher education research centers did not publish articles concerning cross border higher education. Plus, the Ethiopian Journal of Education over the past quarter a century publishes nothing on cross-border higher education. Regarding higher education in Somaliland, precise information on the conflict of franchising mode is not readily available. This study, therefore, is providing baseline information concerning universities franchising mode conflicts and the effect of the conflicts. In addition, studying this problem is so essential to search solutions about the existing conflicts and to suggest what the newly planned Somaliland higher education policy should include, and render clues for further researches. Therefore, the following research question, "What are the reasons behind the conflicts of the franchised cross-border Ethiopian universities in Somaliland higher education and the effect of the conflict on the learningteaching?" is arranged.

\section{Country's Background}

Somaliland is a self-autonomous Islamic country found in eastern horn parts of Africa bordered by Djibouti, Aden gulf, Ethiopia, and Somalia. It lays north of Equator, and it has a coastal line to the north extending $850 \mathrm{~km}$ of Aden gulf coastline. It has an area of 109 square kilometers (Bekalo et al., 2003), a population of 3.8 million (Statistics, 2017). Af-Soomaali (Somali) is the official language of the Republic of Somaliland, and Arabic is the second language (Government, 2000). 
During the scramble for Africa, Somalia was under two European powers. The one that lays to the south was a colony of Italy and was mainly named by Italy Somalia. But the second one which is found to the North West was under British protectorate and called by British Somaliland. On 26 June 1960 Somaliland got full independence through a message by Queen Elizabeth the II saying "Now, therefore, We do hereby, and with the advice or Our Privy Council, proclaim and declare Our protection over Somaliland protectorate shall cease" (Elizabeth, 1960, 24th June). And the southern part also got its independence five days later from Italia, and then the two countries merged and officially formed the Somali Republic.

During the colonial era, when they fought for full independence, the five Somali nations and nationalities found in different five countries: Southeast of Ethiopia, northeast of Kenya, Djibouti, Somaliland, and Somalia had a big plan of merging the five of Somali nations and nationalities in one strong Somalia Republic (Morah, 2000).

At the end of the cold war, the collapse of the East-West contest left the world facing unfamiliar circumstances (Kegley \& Wittkopf, 2006). After the collapse of the East led contest, Siyaad Barre's central government overthrown and the northwest freedom fighters proclaimed its independence as the self-described Republic of Somaliland in May 1991. Autonomous, peaceful, democratic, Islamic and politically stable country has appeared by changing east African affairs profoundly in new but at the same time an old name called Somaliland. However, the self-declared independence remains unrecognized by any country in the word (BBC-NEWS, 2019; Hansen \& Bradbury, 2007; Walls, 2011) except the Ethiopian and Turkey's government by having nominal consulates in the capital Hargeisa.

Even if Somaliland broke up her attachment with Somalia and does not get recognition from the rest of the world, but its political stability, clan-based elders' house, peace and security, free and fair elections together with mixed western democracy and local traditional clan structures referred as encouraging example in Africa.

Relating to higher education, the country unlocked its gate to foreigners equally to local citizens to work in many of the country cities to fill the demand of higher education, and to go ahead for higher education development. Ministry of education \& higher studies is responsible for education in general, and Somaliland national commission for higher education (SNCHE) is responsible for higher education specifically. Hence, this study could also be useful input for the current work of SNCHE. 


\section{Literature Review and Related Theory Brief history of Cross-border Education}

In Europe, Spain was the first to get on the ship and hit the way to Colombia. As (Rosa, Sarrico, Tavares, \& Amaral, 2016) indicated that by the late 16th century, Spain embarked on the first steps in inter-Continental outreach with the founding of two universities in what is present-day Colombia: the Universidad de Santa Tomas de Aquino (1580) and the Pontificia Universidad Javeriana (1623). Outside the UK, 162 years ago, in the year 1858, the University of London independently developed academic programs through which it would validate and award the effort of students. This program was used to validate degrees at institutions throughout the Commonwealth; the institutions were usually granted a royal charter and were referred to as the external college of the University of London (Lane \& Kinser, 2013).

Internationalization is not a new concept for universities (Rosa et al., 2016). Cross-border education, which is part of internationalization, is very aged and it was familiar in Morocco since 859 AD at Karawiyyinn institution, in Egypt since $970 \mathrm{AD}$ at Al-Azhar University, and Timbuktu University in Mali since early $12^{\text {th }}$ century was among the oldest African universities (Njuguna \& Itegi, 2013). These institutions received cross bordered students and scholars and became the center of academic activities. In addition, higher education institutions were crossing borders and met the targeted people formally through formal education in many countries of the world. Among these, educational institutions that opened in France, Italy, and the Panama Canal Zone had come from the United States of America (Lane \& Kinser, 2013).

\section{Franchising Mode and Conflicts}

\section{Meaning of Franchising Mode and conflict}

Franchising is an inter-organizational form that creates a contractual alliance between two firms to generate and allocate a productive benefit (Spinelli \& Birley, 1996). It is a system of relational give-and-take (Kaufmann \& Stern, 1988) in which franchise channel members are commercially interreliant and co-create value through continuing mediation and exchange (Parsa, 1999). As an organizational form, franchising is structured by a long-term contract whereby the owner, producer, or distributor of service or trademarked product (franchisor) grants the non-exclusive rights to a distributor for the local distribution of the product or service (franchisee). According to (Knight, 2005) franchising mode in cross border higher education context is described as "an arrangement whereby a provider in source country A authorizes a provider in country B to deliver its courses programme/service in country B." Like Ethiopian universities in Somaliland, commonly, franchising is 
characterized by a high relational norm of unity. A higher level of franchisee satisfaction increases a franchisee's cooperative intent with the franchisor, leading to lower levels of intra-system conflict (Koza \& Dant, 2007).

Conflict, as a definition by (Dictionary, 2002), is a competitive or opposing action of incompatibles: antagonistic state of action (as of divergent ideas, interest, or persons). It is an unavoidable deep-down part of human being's presence (Wang \& Yotsumoto, 2019). It is the presence of differences, with a primary source of disagreement between two or among many memberships resulting in replying to possible or real obstacles that hinder companion/s from achieving their objectives. In cross-border higher education, the conflicts happen when university programs of the providers are crossing borders through twinning, franchised, articulated, joint, or distance modes. In these modes, there must be two parties. These parties may develop different interests and front conflicts. As (Francis, 2006) defines conflict as the pursuit of mismatched interest and aims by different parties.

\section{Conflict between franchisors \& franchisees, or conflict among shareholders of franchisees}

With franchising mode, there are many countries around the world which names are attached to it. Australia, for example, is respected by the sectors and one of the most densely franchised nations in the world (Terry, 1996). Yet the sector is not free from conflict (Frazer, Weaven, Giddings, \& Grace, 2012). Conflict may damage the quality of relational exchanges (Pondy $\&$ Huff, 1985). This is so dangerous for the existence of healthy relations.

Owing to a perceived disparity of power between franchisors and franchisees, the franchising was regulated in 1998 with the introduction of the Franchising Code of Conduct (Terry, 1996). The main causes of disputes were reported to relate to compliance with the system, misrepresentation issues, profitability, site suitability, territorial issues, communication problems, and franchise fees (Frazer et al., 2012). In addition to this, disputes might occur when earlier conflict is not dealt properly and might damage the franchising relationship totally.

Researchers have most of the time adopted relational exchange/relational equity perspectives to explain the impact of trust, commitment, and relational governance approaches on measurable outcomes such as satisfaction, opportunism, and conflict (Harmon \& Griffiths, 2008). Literature examining franchise performance has focused upon franchisor perceptions of franchisee selection criteria, communication practices, cooperation, and commitment and conflict in franchise systems (Frazer et al., 2012). 


\section{Related Theory}

Studies associated with crossing border education can use the Principal-Agent Theory. This theory is also called by Agency Theory (Alon, $\mathrm{Ni}, \&$ Wang, 2012). It announced that an agency affiliation occurs between the franchisor (the principal/licensor) and the franchisee (the agent/licensee). Based on this, cross border universities (as franchisors) have worked being part of higher education in abroad (as a franchisee) by opening branch campus. The branch campuses answer the need of students in different departments; however, the franchisees focused more on their advantages. As (Hoffman, Munemo, \& Watson, 2016), franchisees can act as self-regulating entrepreneurs, who involve in opportunistic behavior with the goal of improving their units, and who disregard the impact this has on the franchise system. The parties in this relationship may have divergent goals, and related actions may cause agency costs to rise along with the risk of opportunism (Rosado-Serrano \& Paul, 2018). Here, if one party became opportunistic, the sector cannot be free from conflict. So, Principals have the power to reduce agency costs and governor opportunism through direct checking, or through a method of aligned motivations (Alon, 2006). Similarly, the sender (franchisor) university use to contact and try to manage the receiver country (franchisee).

Managers (agents) of company-owned units are less interested to implement efficiently than owners of franchise units because a major component of their compensation is a fixed amount (Rosado-Serrano \& Paul, 2018). Agency theory holds that managers tend to underachieve when their salary is fixed. This underachievement rises monitoring expenses for firms by the franchisor; however, franchisees are owners and managers as well to their own local operation. According to the process of franchising, firms decrease their monitoring costs and handover some of the risks to the franchisee, like sender university (franchisor) do handing over power to the receiver one (franchisee). Thus, firms that participate in franchising are in a better position to enlarge their jobs due to risk-minimizing and monitoring expenses (Hsu \& Jang, 2009). It has been confirmed that agency theory is a useful or dominant approach to study franchising as a business model at an international level (Jang \& Park, 2019), in spite of the fact that the sector is not free from conflict (Frazer et al., 2012). Therefore, to this study, adapting agency theory/principal-agent theory is convenient by keeping the international level of cross-border education.

\section{Research Design and Method}

For this study, the researchers have chosen a qualitative case study design. Case Study which is narrative type checks how individuals experience conflict firsthand (Massey \& Miller, 2018). Narrative analysis has been used to explore conflict as a fantasy theme within negotiation processes (Putnam, 
Van Hoeven, \& Bullis, 1991). Hence, the study tries to explore the reasons behind the conflicts and the effect of the conflicts on the learning-teaching process through a qualitative case study design. Qualitative research enables an in-depth analysis of the problem under investigation (Creswell \& Creswell, 2017).

While deciding about the method of data collection to be used for the study, the researcher should keep in mind two types of data (Kothari, 2004). Data gathered from both primary and secondary sources. Interviews, FGD, document analysis, and observation were data tools.

A semi-structured interview which is one of the three styles of interviews (MacDonald \& Headlam, 2008) conducted at first, before the remaining three data instruments, individually at the convenience of the respective interviewees. The approach of the interview was phenomenological interview. As (Robertson \& Choi, 2012) phenomenological interviews engrossed on the experience of the participants and the meaning, they made of that experience. Consequently, interview questions have designed in light of the theory and the case study proposal, to get information in light of the experience of participants such as the commissioner, presidents and instructors. After designing the interview questions, the researchers consulted the director-general at the ministry of Somaliland education \& higher studies about the two key participants from SNCHE and the remaining twelve participants from five universities. The interview precondition process has guided by (Alshenqeeti, 2014). The voice recording tape, the consideration of participants' time obtainability, the convenience of interview scheduling, explanation of study object, ethical considerations and building the confidence of the interviewee, were taken into consideration and done accordingly. With the consent of some interviewees, data have not been recorded, but notes were taken and transcribed. For the remaining interviewees, data have been recorded. A single interview got finished within an average of $45 \mathrm{~min}$.

In FGD, a group consists typically between 6-10 people (MacDonald \& Headlam, 2008). Next after the interview, six discussants who are student representatives of five different cross border Ethiopian universities spent an hour and a half in the discussion. Since they are student representatives, they know more about students' issues. The initial analyses with the transcripts were sent to both the interview participants and FGD discussants for suggestions and comments, which were used to inform any amendments.

For a better understanding of what is real in Somaliland higher education, a method of document analysis analyzed constitution, contracts, registrar data, legislation and letters with the help of guiding ideas. The guiding ideas were arranged in table to guide the document analysis. As (Merriam, 1998) confirmed documentary sources are key for the qualitative case studies. 
For the period of observation, it is possible to say that the researchers' observation and sense organs help instruments to collect data without asking participants each and everything. As (Kothari, 2004) under the observation method, the information is sought by way of investigator instead of asking the brand of wristwatch used by the respondent may himself look at the watch. At the time of observation, a checklist was arranged and done after document analysis.

In this study, the interpretation of real findings was considered. Interpreting the findings is about checking if the real findings match with previous studies and the theory mentioned. The findings could also be informative. This study focused on the findings arranged in themes. Findings mentioned in four different themes align with the previous studies. The remaining findings arranged in three themes do not align and considered as new findings. Based on this, in the discussion part, a possible explanation is given why some findings align and some others do not.

\section{Sampling and sampling techniques}

The study was done in Somaliland's capital Hargeisa. There are 35 private and government universities in Somaliland. In Woqooyi Galbeed province at the countries capital Hargeisa city 23 universities, in Awdal province at Borama city 6 universities, in Sanaag province at Erigavo city 4 universities, and in Sool province at Las Anod city 2 universities. The capital Hargeisa has many universities compared to all other cities, and all of the cross-border Ethiopian universities have campuses in Hargeisa. The total number of students in Hargeisa is more than all the remaining Somaliland cities. Out of the total 3.8 Million population of the country, one million of them are living in the capital city. Therefore, the population in the city, the total number of universities, the total number of students make the capital Hargeisa could be very good sample representatives.

The study was conducted using participants who have enough information and direct contact with the research problem. Two participants were selected from Somaliland National Commission for Higher Education, a commission that has direct responsibility for Somaliland higher education and accountable to give information in relation to the research problem. In addition, of all 10 cross border Ethiopian Universities, the researchers purposely selected 5 universities: Addis Ababa Medical University College, Admas University, Alpha University, New generation, and Horn University. Even if the level/weight of the conflict differs, but five of the universities had passed through the conflict of either between franchiser \& franchisee or among shareholders of the franchisee. Of the five, Addis Ababa Medical University College's (AAMUC) conflict issue is still on-court progress. These 
purposefully selected universities showed that they have a clear relation to the research problem and, are very near to get surplus data.

Total participants were 14 (4 participants from AAMUC, 2 participants each from the remaining 4 universities, and the other 2 participants from SNCHE). Participants were coded and as indicated in table 1 below, the first letters indicate which university they are from. (e.g AL stands for Alpha University, and AL2 stands for the $2^{\text {nd }}$ participants from the Same University). 
Table 1. Participants' basic information

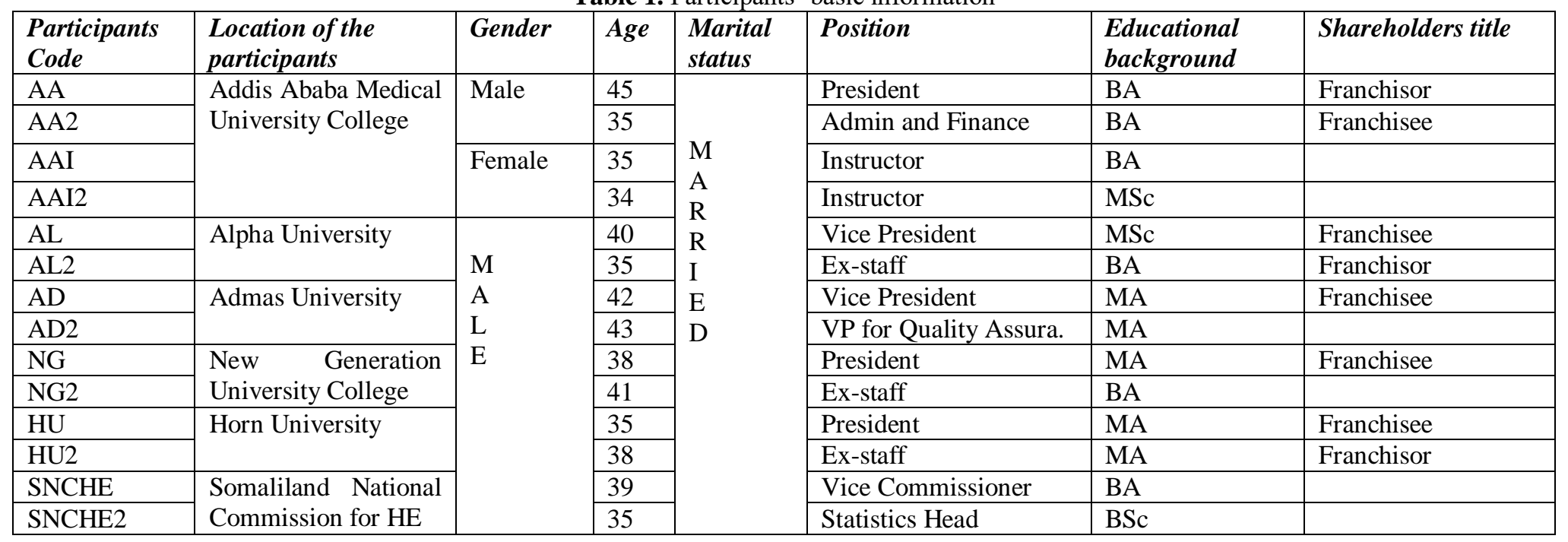




\section{Data Analysis}

There are many ways of analyzing qualitative data and, coding is one of them. It is the major steps (Basit, 2003), and interpretive act (Saldaña, 2015). It is also assigning labels. Therefore, the researchers assign labels to the research question using Anchor codes. Coded the relevant statements and put the codes under the anchor codes. For both interview and FGD data, compiling a list of initial codes were arranged. Then, group code into the anchor code and tally frequency for each code were done. Then, produce category from the codes, and inspect the categories and produce themes. Consequently, seven themes were appeared to respond to the research question. The first four themes show the source of the franchised cross-border universities conflict and the last three themes show the effect of the conflict on the learning-teaching.

Available documents analyzed next to interview and FGD analysis, using critically selected guiding ideas. The guiding ideas indicated what to do when the documents are found. The following documents: franchised agreements/contracts, university legislative, the constitution of Somaliland, incoming and outgoing official letters, registrar data were sought in the office of SNCHE and the universities. These analyzed documents strengthen the data that was collected by other instruments. In addition, observed data were also analyzed at the end. The six items found in the observation checklist with six yes or no columns search similar ideas that can go together with the themes that were earlier arranged by coding.

\section{Reliability and Validity}

To assure data reliability, this case study database upholding the flow of evidences, using many sources of information and the case study protocol leads the data gathering and data analysis. These conserved the process of the reliability of the qualitative data measurement (Yin, 2017). This study has designed a well-organized case study protocol that helps to direct the data gathering process to the attention of the study and the consistency of the process.

The protocol has included questions, rules, data gathering and analyzing procedures, case selection criteria, and overall sequences of activities. The related data types and sources have determined in light of the theoretical research question and empirical evidence. To this end, the research interview questions have developed from the theory called Principal-Agent Theory/Agency Theory. In addition, the researchers tried to use multiple sources of data, and empirical evidence from related studies that have served a conceptual standard for the research question. 
The case study database has established in one of the researchers' laptops. Thus, a flow of evidence also established. This process guided the researchers to concentrate on the thematic areas of the study.

The case study protocol supports the researchers targeted the main attention of the study and prepared the researchers to anticipate different problems that may face in the data gathering process. To assure reliability, the most common approach is to make many procedures as clear as possible. Therefore, the researchers tried to make many procedures and criteria for data gathering and analyzing process in the case study protocol.

In this study, to assure the validity, different data collection methods, such as interview, FGD, document analysis, and observation have deployed. Through the triangulation technique, the validity of the study was maintained. Interview and FGD were supported by document analysis and observation. Triangulation is qualitative cross-validation that assesses the sufficiency of the data according to the convergence of the multiple data collection procedures (Wiersma, 1985). Using multiple sources of data in a case study made the findings and conclusions more convincing and accurate. In addition, all instruments prepared by the researchers in English language and the instruments were piloted for their validity by taking colleagues who are thoughtful, critical, and similar to research participants

\section{Findings from the data}

The study undertook interview, FGD, observation, and available document analysis, and found out the following findings.

\section{Failure to abide by the contract}

The interview result from the participants revealed that, of all the ten cross border Ethiopian universities, seven of them are currently functional, and of the seven functional cross border Ethiopian universities in Somaliland, six of them: Addis Ababa Medical University College, Alpha University, Admas University, Horn University, New Generation University College and Addis College had a conflict because of failure to abide by the contract. The failure to abide by the contract can be divided into two. These are the franchisor and franchisee failure to abide by the contract and shareholders of franchisees' failure to abide by the contract.

\section{Franchisor and franchisee failure to abide by the contract}

Here the conflicts appeared because the two parties refused to obey the contract. For a simple example, the AAMUC's case between the franchiser and franchisee has been on court progress since 2011. The document analysis shows that the contract made in line with Civil Code No. 2727 between Addis Ababa Medical University College's licensor and the licensees is clearly 
mentioned how the two parties to be governed by it, but the old shareholders among franchisee are not always ready to be abided by the contract. Instead, they wait till someone brings their conflict to the court. As the first participant AA said, each article in the contract has clearly stated what the franchisee should do, however; they do not comply with it in practice. For instance, under the contract between AAMUCH's franchisee and franchisor on article 3 about 'Obligation of the Franchisee' the sub-articles from 3.1 to 3.9 could lead to solutions or remedies when a disagreement happens.

From one of the researchers' personal experiences, shareholders of franchisees disrespect the contract and consider it as nothing. They show reluctant to send/announce the exact number of newly registered students and the money that is expected to be deposited monthly or quarterly. Participant SNCHE also mentioned the system is not networked, so, unless the exact total number of newly registered students confirmed, it may lead to a conflict that happens at last semester when the franchisees ask degree certificates from the franchiser.

\section{Shareholders of franchisees' failure to abide by the contract}

The response of participants showed franchisees' failure to abide by the contract became the source of conflict. Two interests are major sources.

\section{A) Position/seat interest}

Extra position/seat interest appears in the universities' administrative/supportive offices after signing the contract and joins to the work. This position is another source of money/salary in addition to franchisee member profit allocation. Hence, this position interest got support from one or two of the franchisee members. The other one or two members loose trust in the first two and these lead them not to abide by the contract. During the interview, participant AA2 said, giving service in the education sector is more than the interest of a personal position.

\section{B) Financial interests}

Financial interests were a major source of conflict. In addition to the common/annual expected profit share of the shareholders, other collected money also the source of conflicts. HU said, for very many reasons, money is collected throughout the academic years. He added that the collected money seems a small amount but it's too much. HU2 said, re-exam, add \& drop, exemption, graduation ceremony, late registration penalty, documentation payment, discipline committee decision in payment other miscellaneous payments were the source of income and at the same time it was the source of conflicts. These financial interests became a problem of teaching-learning processes. The document analysis in the finance office and observation strengthen that there is a source of money from different payment reasons. 
During many of the conflicts, these incomes had not been considered accurately in the contract and latter create a question of to whom these incomes should be given.

\section{Absence of Trust in the Franchise Relationship}

The response of the participants showed absence of trust in the franchise relationship focused on two issues. These two are absence of trust on a day to day duties, and absence of trust in getting degree certificate.

\section{Absence of trust on a day to day duties}

The interviewees showed the importance of the two parties' trustworthiness in facilitating productive relational exchanges. Participants HU and SNCHE2 clearly mentioned that trust has a significant role in managing day to day duties and on the expected satisfaction that franchisee and franchisor deserve. But trust as a significant antecedent of successful franchise relationship would not be seen between the two parties and among shareholders of the franchisee in Somaliland. One of the authors had previous experience of observing two court arguments. The first one is between the defendant franchisor and the plaintiff franchisee. The second one is among members of the franchisee. Both arguments were rotating a lack of trust. One does not relay the other whom the staff, stakeholders, universities, and higher education commission believe.

Participants AL2 and AA2 mentioned that students deposit semester payments at Dahabshiil Bank. Hence, one of the cross-checking that helps the franchisor and the franchisee is the bank statements. Thus, the two parties must be reliant on the statement. But forwarding minor issues in the campuses finance office could create conflict and develop the relationship of "I do not trust you".

Openness, honesty, support, good communication between campuses in Ethiopia and Somaliland are beneficial for both parties. The participants' AL and HU2 said being a good franchisor is about communicating with the franchisees trustfully. Because the expected mandatories and supports that franchisor provided to the franchisee impacted on the goal of cross border education's further relation. In addition, the same participants mentioned that lack of communication or communication within a long period of time might contribute some to the conflict we had. The two parties should communicate which has to be opened to all parties. AA said trust helps two parties handling, negotiating and problem-solving, though preserving trust in a situation where the parties' interests do not concur is usually a tough process. Participant NG said franchisee system should encourage relational trust; otherwise, it loses tightening up of cooperation between parties. 


\section{Absence of trust in getting degree certificate}

During the interview, participant HU confirmed Horn University has not got the last two batches graduate students certificate. FGD discussants also confirmed the case of these two batches certificates. AL also mentioned, Alpha university Somaliland campus also bringing high-quality certificates from the United Kingdom, even if the certificates does not approve by the main campus in Ethiopia. In addition, at AAMUC getting degree certificate in every academic year has doubts among franchisor and franchisee. AA2 said the absence of trust makes getting degree certificates at the end of each academic year the toughest assignment.

\section{The delay of the involvement of the Somaliland National Commission for Higher Education}

Participants AL2 \& HU2 shared their previous office experience listing, three parties namely: shareholders, government/public, and staff. They have further explained that shareholders get a large portion of the profit that the institutions earn in each academic year. The government/public gets the benefits as human capital (graduated students in BA and MA degrees) that is skilled and knowledgeable to work in the different public institutions in the country. The staff gets job promotion for a better life/salary to their family. Here, most conflicts aroused by the first party (shareholders). Therefore, since the National Commission for Higher Education has interest and official vested power, it should be powerful to interfere and solve conflicts. But during the interview, both participants SNCHE \& SNCHE2 from Somaliland National Commission for Higher Education have confirmed that the commission's immediate response is so late and possible to say unseen. The commission waits until the issue/conflict appears at the court passing through its office. To secure its advantage and at the same time to exercise its power, the commission is not as such fast during the conflict.

In another interview, participant AA2 point out the SNCHE's weakness in exercising its power. He mentioned, what I know is the commission is neglecting different institutions' conflicts. Indeed, the participant added that universities cross bordering experiences are found all over the world. He noted as a simple example, New York University operates in the United Arab Emirates funded by the UAE Ministry of Education. So, if the difficult one, funding, is covered in another country and managed it smoothly, how SNCHE cannot control the easiest one which is immediate control over the franchised agreement and entrance license criteria properly?

Participants AD \& AA2 inquired and also answered at the same time saying 'no reason hidden the problem since the national commission is found under the Ministry of Education'. The participants commented, towards this end, special department ought to open under higher education commission. By 
opening a new department, the working spirit would be strengthened in higher education commission to observe the progress of all franchised universities, to motivate the staff of the universities and to keep the expansion of Somaliland higher education as well.

\section{Running higher education without higher education policy}

All the data clearly showed that Somaliland does not have higher education policy. Somaliland has only primary and secondary education policy. The absence of higher education policy makes office of the higher education confused. Both participants: SNCHE \& SNCHE2 obviously mentioned that they are running higher education without higher education policy. They added, the draft of higher education policy is ready and submitted to the Somaliland parliament and waiting for approval. Participant NG has reminded they send their expert to contribute professional ideas for the planned higher education policy during policy-making process.

Participant AAI has believed that Somaliland higher education is under the influence of Ethiopian higher education policy. AD2 has mentioned, Ethiopian delegates from Higher Education Relevant Quality Assurance (HERQA) started crossing the border of Somaliland and accredit cross border Ethiopian universities. AA added, based on this accreditation, Somaliland National Commission for Higher Education and the stakeholders (students, parents, and teachers) accept HERQA's decision. The document analysis at Admas University in Somaliland showed that delegates from Ethiopian's HERQA approved the accreditation of the university for three consecutive academic years up to June/July 2020. During the observation, it is also observed the university staff and students give more focus on what HERQA said rather than SNCHE.

\section{Interruptions of the learning-teaching}

From one of the researchers' personal experience in the research area, Ethiopian (sender country A) universities after being part of Somaliland (receiver country B) higher education, some conflict cases pass through country A first and goes to country B. Even if most court cases appear and end up too in country B, but some cases passes through in both sender and receiver countries' different concerned government offices like embassy, ministry of foreign affairs, justice minister, banks e.t.c, and make the court issue stay long to get solution. Staying long means, if there is a temporary court injunction of learning-teaching interruption to the defendant until the injunction is canceled and begin the class again, the campus is shut down and the learning-teaching becomes interrupted. Once, AAI2 said, I met no student for a couple of weeks, and I tested being jobless for the first time in my life. Being jobless when the injunction comes was also mentioned during the FGD discussion. Participant 
AA2 remind two interruptions and said the second was only for a week. In the document analysis, two letters written on different days notify students to wait very few days till the learning-teaching resume.

\section{Influencing quality maintenance}

At the time when the university management dragged to focus on the court issue and the campus is temporarily closed, maintaining internal quality is neglected, HU2 said. Another participant NG2 mentioned university management is a major actor in playing an important role in quality learningteaching. But if their tension and expense is occupied by court issues, they would not be motivated to do their best for quality learning-teaching. AL2 added there was one big conflict. Hence, instructors' interest in the courses they teach, communication among staff members \& students, and institutional self-assessment was neglected. After the injunction, AAI2 said, for some 2/3 weeks academic staff commitment to implement academic calendar properly becomes weak. Students' interest to attend in the library and demonstration starts again from scratch like starting a new academic semester.

\section{Students transfer}

Cross border Ethiopian universities appeared in Somaliland at first in 2006. Since that moment on together with the transfer of knowledge and skills, conflicts appear as well. The conflicts forced students to face transfer from their university to another. During FGD discussants said, finding transferred students because of the conflict is an easy task. The document analysis in two universities showed that the number of students, in the academic year 2013, 2014, and 2015 before and after conflicts, has clear difference of declination. Because of the conflicts, including $4^{\text {th }}$ year expected graduates, have got a transfer to different local and foreign universities. By the case of transferred students, participant AAI and HU2 mentioned, some departments reached up to calling-off the departments for one or two academic year/s.

\section{Needless Payment}

During FGD, of the total six discussants, two of the discussants family member got transfer from their previous university to the current one. Many of the students batches did the same. The only reason for their transfer was the conflict in their campus. They decided to pay the demanded payment US dollars 150 and got transfer to the university. Participant SNCHE2 indicates students become vulnerable for the payment at the time of transfer after conflict. He added, their source of money is from their parents. Participant AAI2 said many of the students are waiting all semester long to get funds from their diaspora relatives. During the observation, it is confirmed that getting student copy before having transfer charges from US dollars 50 to 150. 


\section{Stakeholders' suspicion towards cross border universities}

Originally, participant AA2 said, all cross border universities had very good acceptance within the heart of the people, later the conflict hurt the goodwill of border crossing universities. During one of the researchers' employees stay in the study area, stakeholders (especially parents) told senior officials that cross borders universities are ruining their good names. The parent added that "the confidence and the love I had for all cross border universities quite differ from what I have now."

As it was mentioned by AA2, stakeholders view such as the public, students, professionals, alumni, and staff towards the franchised universities now a day has suspicion. As it was mentioned by FGD discussants, and widely believed in the capital city that Somali people are oral society. Therefore, if any university having earlier or current conflict among shareholders of the franchisee, the progress of shareholders' court case is transferred orally and known by all people in the capital city, a capital having a total population of 1 million. Hence, this rumor has an influence on the stakeholders' attitudes towards the universities.

\section{Discussion}

Since the history of cross border higher education started in 2006 in Somaliland, there is no research done on cross border higher education franchising mode conflicts in Somaliland. But this research tried penetrating the research problem and found out the above shown similar and at the same time dissimilar findings comparing to the previous research problem. The findings are different reasons for the conflicts of the franchised cross-border Ethiopian universities, and the effects of the conflicts on the learning-teaching in Somaliland Higher education. The conflicts appeared because the franchisors and the franchisees refused to obey the contracts, and this forced them to stand on the court. In addition, seat/position and financial interests among shareholders of franchisees are other sources of the conflicts. This is because of the absence of trust in the franchising relationship, and there is no active involvement of the SNCHE to manage the conflict and to exercise its power. These different reasons lead to the result of interrupting the learningteaching and influence on quality maintenance, students transfer together with needless expensive payments and stakeholders' suspicion towards cross border universities.

The research could go similarly to the previous findings, and at the same time, brings up new findings. According to (Frazer et al., 2012), the Australian franchising sector has been attended by tension, disputes, and conflicts as this study has found out similar problems. The Australian case dragged concerned regulatory bodies as this study assure that the two parties were looking for court mediation after they fail to abide by the contract. In 
addition, two different studies (Merrilees, 2014) and (Altinay, Brookes, Madanoglu, \& Aktas, 2014) have shown trust and communication are essential elements in parties' relationship, and whenever and wherever they are the matrix for the success of the franchising. The same is true, this study found out that; this absence of trust is the cause of conflicts in franchised cross border Ethiopian universities in Somaliland higher education.

Both the absence or delay of SNCHE to involve itself in the mediation or decision-making process and the absence of higher education policy in Somaliland which indicates about how cross border universities are governed are big problems of the Somaliland higher education and considered as new findings of the study that have not been found out earlier as reasons for cross border higher education franchising mode conflict.

The authors had believed that student transfer and needless payment is considered as a minor issue and previous researches did not give attention to how it is a problem to the stakeholders especially to the students and students' parents. Indeed, a study (Robison, Fawley, \& Marshall, 2019) mentioned firstdegree students who transfer from their university to another if they face rough academic experiences or other seniors got transfer to complete their final at a brand new institution. These two sample transfers done by the interest of students to be advantageous. But in this study what happened is students forced to have transferred from their university to another because of conflicts consequences. When the campuses reach to court injunction it takes time to call off the injunction and resume the learning-teaching. This forcing factor also pushed students or student parents to pay an exaggerated payment for the educational documents before they got a transfer to another university.

Principal-agent theory (agency theory) assures the attachment of two different parties. Hence, Ethiopian universities as the franchisor (the principal/licensor) cross the border of Somaliland using franchising mode agreement with the franchisee (the agent/licensee) and open branch campus in one or more than one cities for the benefit of the cities. As (Kurowska-Pysz, 2016) territorial partnership is based on the agreement between three or above partners for the benefit of the specific region. But, when Ethiopian franchisors and Somaliland franchisee or shareholders of Somaliland franchisees do not perform their duties \& responsibilities properly means, conflicts arise and bring court issue and the flow of the learning-teaching process is interrupted. Plus, stakeholders suspicion towards cross border universities increased. This means that, in addition to the risk of cross border higher education, as a country, it could also warn other social cross border cooperation like tourism, culture, and sport. 


\section{Limitation}

The study was conducted through a qualitative approach, not a mixed approach of both qualitative and quantitative to include the respondents of stakeholders especially parents and alumni through large-scale surveys. It was also done on only cross border Ethiopian universities that did not include other countries cross border universities in Somaliland. Moreover, further study should be done to reveal extra reasons behind the conflicts and to get rid of the source of the active nature of franchising mode conflicts at all in cross border higher education.

\section{Conclusion}

The government of Somaliland has got on expanding higher education and foreign educational institutions grounded on the country's constitution. This results in commencing cross border education through inter-reliant long term contractual alliance; however, it introduces risks to the learning-teaching. Because how to manage the cross border universities without conflict and to let the universities contribute tangible assets for the development of the young higher education in the country is one of the most important things. Therefore, responsible and trusted franchisors and shareholders franchisees, together with highly tight franchising mode contract that should actively be controlled by SNCHE, would protect conflicts in prior. Currently, Somaliland does not have a higher education policy. But the new higher education policy, which is now on draft stage presented to the parliament and waiting for approval, should clearly includes/states how cross border higher educations should be governed. At large view, it is also helpful for the safe moving ahead from elite to mass higher education of the de facto independent state of Somaliland.

\section{References:}

1. Aga, F. J. (2006). Quality assurance in higher education institutions: challenges and opportunities. IER FLAMBEAU, 14(1), 29-42.

2. Ali, M. (2014). Building state capacity in a post-conflict situation: the case of Somaliland. American International Journal of Contemporary Research, 4(1), 157-170.

3. Alon, I. (2006). Market conditions favoring master international franchising. Multinational Business Review, 14(2), 67.

4. Alon, I., Ni, L., \& Wang, Y. (2012). Examining the determinants of hotel chain expansion through international franchising. International Journal of Hospitality Management, 31(2), 379-386. doi:10.1016/j.ijhm.2011.06.009

5. Alshenqeeti, H. (2014). Interviewing as a data collection method: A critical review. English linguistics research, 3(1), 39-45. 
6. Altinay, L., Brookes, M., Madanoglu, M., \& Aktas, G. (2014). Franchisees' trust in and satisfaction with franchise partnerships. Journal of Business Research, 67(5), 722-728.

7. Basit, T. (2003). Manual or electronic? The role of coding in qualitative data analysis. Educational Research, 45(2), 143-154. doi:10.1080/0013188032000133548

8. BBC-NEWS. (2019). Ethiopia apologises for map that erases Somalia. Retrieved from https://www.bbc.com/news/world-africa-48421416

9. Bekalo, S. A., Brophy, M., \& Welford, A. (2003). The development of education in post-conflict 'Somaliland'. International Journal of Educational Development, 23(4), 459-475.

10. Bertoni, E., Di Maio, M., Molini, V., \& Nisticò, R. (2018). Education is forbidden: The effect of the Boko Haram conflict on education in North-East Nigeria. Journal of Development Economics. doi:10.1016/j.jdeveco.2018.06.007

11. Creswell, J. W., \& Creswell, J. D. (2017). Research design: Qualitative, quantitative, and mixed methods approaches: Sage publications.

12. Dictionary, M.-W. (2002). Merriam-webster. On-line at http://www. mw. com/home. htm.

13. Elizabeth. (1960, 24th June). Terminating Her Majesty's Protection Over The Somaliland Protoctorate. The London Gazette

14. Francis, D. J. (2006). Peace and conflict studies: An African overview of basic concepts. Introduction to peace and conflict studies in West Africa: a reader. Ibadan: Spectrum Books Ltd.

15. Frazer, L., Weaven, S., Giddings, J., \& Grace, D. (2012). What went wrong? Franchisors and franchisees disclose the causes of conflict in franchising. Qualitative Market Research: An International Journal, 15(1), 87-103. doi:10.1108/13522751211192017

16. Government, S. (2000). CONSTITUTION OF THE REPUBLIC OF SOMALILAND.

17. Hansen, S. J., \& Bradbury, M. (2007). Somaliland: A New Democracy in the Horn of Africa? Review of African Political Economy, 34(113), 461-476. doi:10.1080/03056240701672585

18. Harmon, T. R., \& Griffiths, M. A. (2008). Franchisee perceived relationship value. Journal of Business \& Industrial Marketing, 23(4), 256-263.

19. Hoffman, R. C., Munemo, J., \& Watson, S. (2016). International Franchise Expansion: The Role of Institutions and Transaction Costs. Journal of International Management, 22(2), 101-114. doi:10.1016/j.intman.2016.01.003 
20. Hsu, L.-T., \& Jang, S. (2009). Effects of restaurant franchising: Does an optimal franchise proportion exist? International Journal of Hospitality Management, 28(2), 204-211. doi:10.1016/j.ijhm.2008.07.002

21. Jang, S., \& Park, K. (2019). A sustainable franchisor-franchisee relationship model: Toward the franchise win-win theory. International Journal of Hospitality Management, 76, 13-24. doi:10.1016/j.ijhm.2018.06.004

22. Kaufmann, P. J., \& Stern, L. W. (1988). Relational exchange norms, perceptions of unfairness, and retained hostility in commercial litigation. Journal of conflict resolution, 32(3), 534-552.

23. Kegley, C. W., \& Wittkopf, E. R. (2006). World Politics: Trend and Transformation: Thomson Higher Education.

24. Knight, J. (2005). Crossborder Education: Programs and Providers on the Move. CBIE Research Millennium Series No. 10: ERIC.

25. Knight, J. (2010). Higher education crossing borders. Cross-border partnerships in higher education: Strategies and issues, 16-41.

26. Kothari, C. R. (2004). Research methodology: Methods and techniques: New Age International.

27. Koza, K. L., \& Dant, R. P. (2007). Effects of relationship climate, control mechanism, and communications on conflict resolution behavior and performance outcomes. Journal of Retailing, 83(3), 279296. doi:10.1016/j.jretai.2007.03.002

28. Kurowska-Pysz, J. (2016). Opportunities for Cross-Border Entrepreneurship Development in a Cluster Model Exemplified by the Polish-Czech Border Region. Sustainability, 8(3). doi:10.3390/su8030230

29. Lane, J. E., \& Kinser, K. (2013). Cross-Border Higher Education in Africa: Collaboration and Competition The development of higher education in Africa: Prospects and challenges (pp. 99-126): Emerald Group Publishing Limited.

30. MacDonald, S., \& Headlam, N. (2008). Research Methods Handbook: Introductory guide to research methods for social research: Centre for Local Economic Strategies.

31. Massey, Z. B., \& Miller, C. H. (2018). Case studies on interethnic conflict: A theoretical integration. International Journal of Intercultural Relations, $\quad 66, \quad 130-147$. doi:10.1016/j.ijintrel.2018.04.006

32. Merriam, S. B. (1998). Qualitative Research and Case Study Applications in Education. Revised and Expanded from" Case Study Research in Education.": ERIC. 
33. Merrilees, B. (2014). International franchising: Evolution of theory and practice. Journal of Marketing Channels, 21(3), 133-142.

34. Morah, E. U. (2000). Old institutions, new opportunities: the emerging nature of Koranic schools in Somaliland in the 1990s. International Journal of Educational Development, 20(4), 305-322.

35. Njuguna, F. W., \& Itegi, F. M. (2013). Cross-border higher education in Africa: The Kenyan experience. Journal of Emerging Trends in Educational Research and Policy Studies, 4(5), 752.

36. Parsa, H. (1999). Interaction of strategy implementation and power perceptions in franchise systems: an empirical investigation. Journal of Business Research, 45(2), 173-185.

37. Pondy, L. R., \& Huff, A. S. (1985). Achieving routine in organizational change. Journal of Management, 11(2), 103-116.

38. Putnam, L. L., Van Hoeven, S. A., \& Bullis, C. A. (1991). The role of rituals and fantasy themes in teachers' bargaining. Western Journal of Speech Communication, 55(1), 85-103. doi:10.1080/10570319109374372

39. Robertson, P. J., \& Choi, T. (2012). Deliberation, consensus, and stakeholder satisfaction: A simulation of collaborative governance. Public Management Review, 14(1), 83-103.

40. Robison, M., Fawley, N., \& Marshall, A. (2019). "That background knowledge": What junior and senior undergraduate transfer students need from their libraries. The Journal of Academic Librarianship, 46(1). doi:10.1016/j.acalib.2019.102092

41. Rosa, M. J., Sarrico, C. S., Tavares, O., \& Amaral, A. (2016). CrossBorder Higher Education and Quality Assurance: Commerce, the Services Directive and Governing Higher Education: Springer.

42. Rosado-Serrano, A., \& Paul, J. (2018). A new conceptual model for international franchising. International Journal of Hospitality Management, 75, 179-188. doi:10.1016/j.ijhm.2018.05.024

43. Saint, W. (2004). Higher education in Ethiopia: The vision and its challenges. Journal of Higher Education in Africa, 2(3), 83-113.

44. Saldaña, J. (2015). The coding manual for qualitative researchers: Sage.

45. Spinelli, S., \& Birley, S. (1996). Toward a theory of conflict in the franchise system. Journal of Business Venturing, 11(5), 329-342.

46. Statistics, S. C. (2017). Latest Statistics Available from Somaliland Ministry of Planning and National Development Retrieved 23 July 2019 www.somalilandcsd.org

47. Terry, A. (1996). The regulation of franchising in Australia: Reviews, roundabout and Realpolitik. Paper presented at the Society of Franchising Conference, Hawaii. 
48. Walls, M. (2011). State formation in Somaliland: bringing deliberation to institutionalism. UCL (University College London).

49. Wang, L., \& Yotsumoto, Y. (2019). Conflict in tourism development in rural China. Tourism Management, 70, 188-200. doi:10.1016/j.tourman.2018.08.012

50. Wiersma, W. (1985). Research methods in education: An introduction.

51. Yin, R. K. (2017). Case study research and applications: Design and methods: Sage publications.

\section{Appendices}

\section{Appendix A- Interview questions}

1. What are the reasons behind the conflicts on the franchising mode contract?

2. What are the effects of the conflicts on the overall learning-teaching process?

3. Do you think franchising mode contract is implementing properly? If so how if not, why?

\section{Appendix B- FGD question}

1. What does the conflict bring in your personal or family life? 